\title{
Water management system of peatlands for palawija plants on KHG Pulang Pisau, Central of Kalimantan
}

\author{
Fadel Khalifah Ibrahim ${ }^{1, *}$, Yadi Suryadi ${ }^{2}$, Indratmo Soekarno ${ }^{2}$, Sri Legowo ${ }^{2}$, Mohammad Bagus Adityawan $^{2}$, and Saepul ${ }^{1}$ \\ ${ }^{1}$ Center for Water Resources Development, Institute for Research and Community Services, Institut Teknologi Bandung, Bandung, \\ Indonesia \\ ${ }^{2}$ Water Resources Engineering Research Group, Faculty of Civil and Environmental Engineering, Institut Teknologi Bandung, \\ Bandung, Indonesia
}

\begin{abstract}
Kesatuan Hidrologis Gambut (KHG) or Peat Hydrological Unit is a land which consist of incomplete soil decomposition of aquatic vegetation that is inundated with anaerobic conditions. Peatlands in Indonesia have common problem, which is adequacy of water availability (water balance) throughout the year and fire risk. This condition makes the holding of studies to ensure this. In this research, study uses secondary data of Peatlands, Pulang Pisau regency, Central of Kalimantan. This research will be modeling groundwater level using unconfined steady aquifer with finite difference method by Qgis Freewat. Then, if possible, the model will be calibrated by direct sampling at some point in the field, so the next will be modeling by comparison results of water level model with water level existing that up to $40 \mathrm{~cm}$ in accordance with Government Regulation no. 57 of 2016 on amendment to Government Regulation No. 71 of 2014 on the Protection and Management of Peat Ecosystems. From this research is expected to give some of benefits as follow: 1). Estimating water balance for Palawija Plants in KHG Pulang Pisau, 2). Modeling groundwater level for canal as one of the optimal water management efforts so that peatlands are not too dry and not too wet, so the risk of forest fires can be minimized.
\end{abstract}

\section{Introduction}

The peat ecosystem is a unit of peat element which influences each other in forming a stability, equilibrium and productivity [1]. The function will decrease if the hydrological function of the peatlands decreases. To protect it, efforts are made to plan, utilize, control, maintain, supervise and enforce the law, which is then known as the peatlands water management system. Objectives of this study are:

1) Analyzing water balance for Palawija Plants in KHG Pulang Pisau.

2) Analyzing the water level of groundwater peatlands in KHG Pulang Pisau,

3) Analyzing parameter for water managements system of peatlands in KHG Pulang Pisau.

\section{Scope}

1) Estimation of water balance in the study area based on Hydrological data at 1987-2002.

2) Modeling groundwater level of peatlands for drainage/ canal

\section{Methodology}

This study focuses on Sub KHG 1 on Pulang Pisau Regency, Mulyasari district. This location is located between Kahayan River and Sebangau River with land area $1.786 \mathrm{~km}^{2}$ and topographic variation $0-10 \mathrm{MSL}$. Fig. 1, Fig.2 and Fig 3 below are location research conducted.

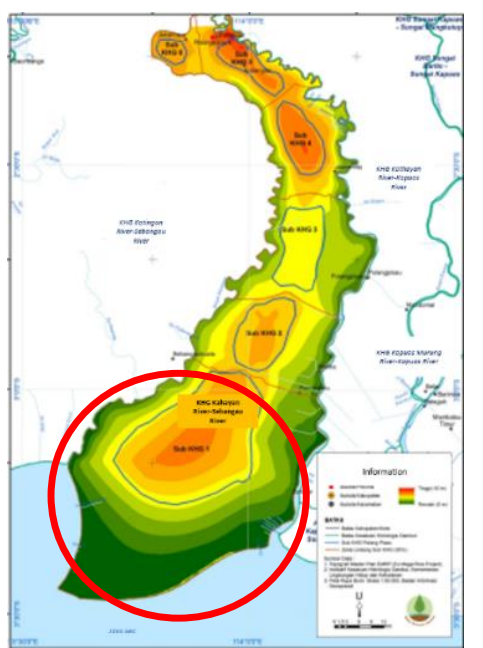

Fig. 1. Location Sub KHG 1 Pulang Pisau

(Source: Peat Restoration Agency of Republik Indonesia, 2016)

\footnotetext{
* Corresponding author: fadelkhalifah@gmail.com
} 


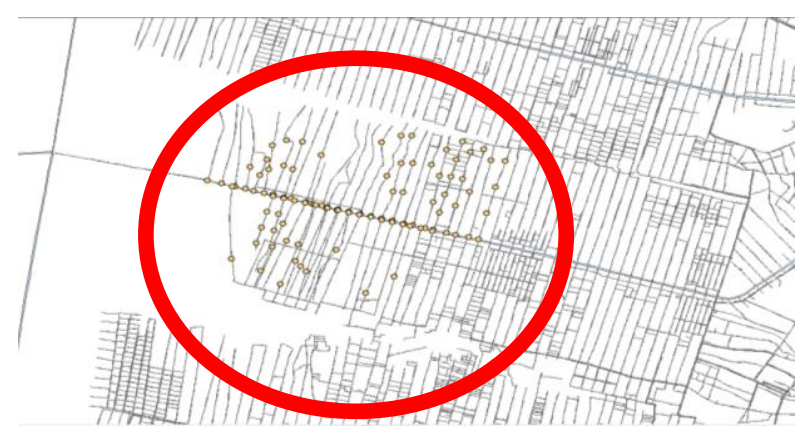

Fig.2. Mulyasari village on Sub KHG 1

The sub-KHG Mulyasari above were determined based on the assumption of water dome service to the surrounding area is $30 \%$ (flow between the Kahayan River and Sebangau River.

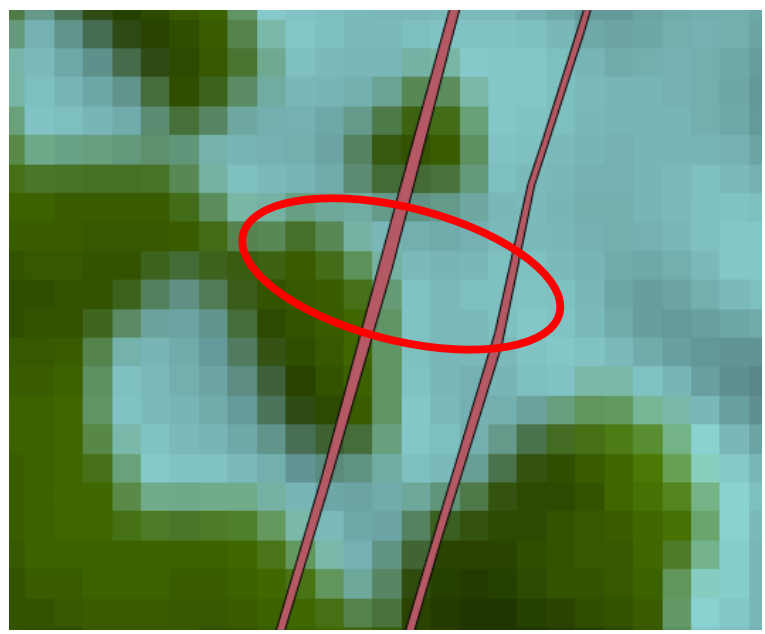

Fig.3.Canal Location Study on Mulyasari Village

Based on Peat Restoration Agency of Republik Indonesia, Sub KHG 1 serving area as large as 775.321 $\mathrm{m} 2$ with volume $895.840 .162 \mathrm{~m}^{3}$. The study focuses on one of secondary canal which connected with primary channel and tertiary channel and supplied by catchment as Fig. 4 below

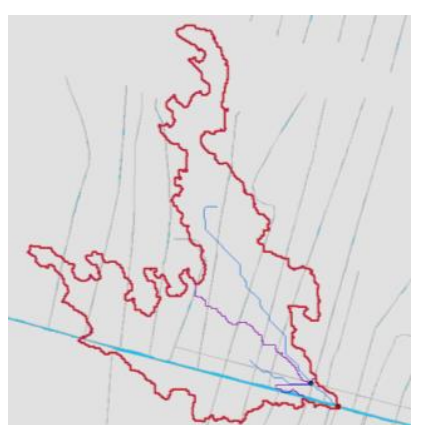

Fig. 4. Catchment area by outlet at secondary canal

In the water balance analysis, what will be examined is a description of the availability of water resources based on the comparison between water requirements and water availability. So that to calculate the equilibrium of water, it is necessary to know the factors that influence the equilibrium of water in the land.

Whereas for groundwater modeling is intended to determine the behavior of groundwater movement in the hydrogeological system in the study location. Modeling will use Freewat Software with the Modflow module which is a plugin from Q Gis 2.18 Las Palmas.

\section{Results and analysis}

\subsection{Rain and climatology}

In this study, the rainfall data uses rainfall data obtained in 1987-2002. Source data from Hujan, Mantaren Station. The results of regional rainfall analysis come form is thiessen polygon analysis method.

Table 2. Rainfall area analysis

\begin{tabular}{|c|c|c|c|c|c|c|}
\hline \multirow{3}{*}{ No } & \multirow{2}{*}{ Years } & \multicolumn{4}{|c|}{ Stations } & \multirow{2}{*}{ Rainfall Area } \\
\hline & & Mandomai & Mantangai & B.Bengkel & Mantaren & \\
\hline & & 0.005459118 & 0.008435476 & 0.154801091 & 0.831304315 & $\mathrm{~mm}$ \\
\hline 1 & \begin{tabular}{|l|}
1987 \\
\end{tabular} & 83 & 100 & 104 & 78 & 82 \\
\hline 2 & 1988 & 67 & 123 & 163 & 150 & 151 \\
\hline 3 & 1989 & 97 & 65 & 88 & 75 & 77 \\
\hline 4 & 1990 & 80 & 55 & 101 & 82 & 85 \\
\hline 5 & 1991 & 83 & 51 & 81 & 75 & 76 \\
\hline 6 & 1992 & 97 & 66 & 93 & 0 & - \\
\hline 7 & $\mid 1993$ & 51 & 60 & 109 & 85 & 88 \\
\hline 8 & 1994 & 100 & 46 & 120 & 170 & 161 \\
\hline 9 & 1995 & 84 & 55 & 136 & 150 & 147 \\
\hline 10 & 1996 & 80 & 83 & 63 & 130 & 119 \\
\hline 11 & \begin{tabular}{|l|}
1997 \\
\end{tabular} & 53 & 40 & 88 & 180 & 164 \\
\hline 12 & \begin{tabular}{|c|}
1998 \\
\end{tabular} & 68 & 92 & 113 & 300 & 268 \\
\hline 13 & \begin{tabular}{|l|}
1999 \\
\end{tabular} & 77 & 52 & 83 & 100 & 97 \\
\hline 14 & 2000 & 55 & 36 & 111 & 300 & 267 \\
\hline 15 & 2001 & 65 & 26 & 120 & 200 & 185 \\
\hline 16 & 2002 & 117 & 40 & 111 & 300 & 268 \\
\hline
\end{tabular}

(Source: Rainfall Data Analysis, 2018)

and below, climatology data in area study [2].

Table 3. Parameter of climatology Pulang Pisau regency

\begin{tabular}{|c|c|}
\hline Parameter & Value \\
\hline Temperature $\left({ }^{0} \mathrm{C}\right)$ & $27,0{ }^{0} \mathrm{C}-28,1^{\circ} \mathrm{C}$ \\
\hline Humidity $(\%)$ & $81,0 \%-84,0 \%$ \\
\hline Duration of Shine (\%) & $1372,5-1987,5 \%$ \\
\hline $\begin{array}{c}\text { Atmospheric Pressure } \\
(\mathrm{mb})\end{array}$ & $1011,2-1013,6$ \\
\hline
\end{tabular}

(Sources: BPS-Statitic of Pulang Pisau Regency, 2018 on Meteorological Stations Tjilik Riwut Palangka Raya, Meteorology, Klimatology, Geophysics, 2018)

\section{Water balance estimation}

KHG Kahayan-Sebangau is located in the delta with lowland landscapes. Based on topographic data, the results of the analysis show that there is no significant influence of water from the surrounding land into the KHG (KHG Kahayan-Sebangau), both in the form of surface flow and groundwater. The annual water balance of peatlands in the study location is dominated by rainfall as its main input, and evaporation as the main output. This output occurs through a rapid increase in debit, especially during the rainy season, while the proportion of ground water itself is quite small. In summary, this water balance can be seen in the following equation: 


$$
\Delta \mathrm{S}=\mathrm{P}(\ldots . . \mathrm{mm})-\text { Qs.o. }(825 \mathrm{~mm})
$$$$
\text { - Qg.o (2755 mm) - (ET+I) (1650) }
$$

At each rainfall station, water balances estimation is performed by using the F.J Mock method obtained the value of Q80 discharge for 15 daily from 1987-2002 at each station as follows.

Below, flowchart working steps of the dependable flow F.J Mock method.

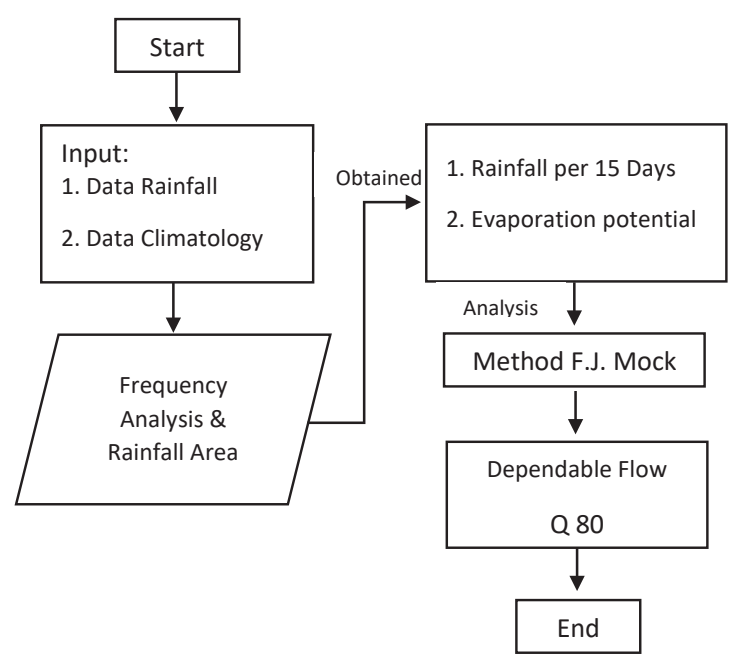

Fig.5. Q 80 F.J. Mock Mantaren Stat. 1987-2002 (Source: Analysis Data, 2018)

\subsection{Mantaren station}

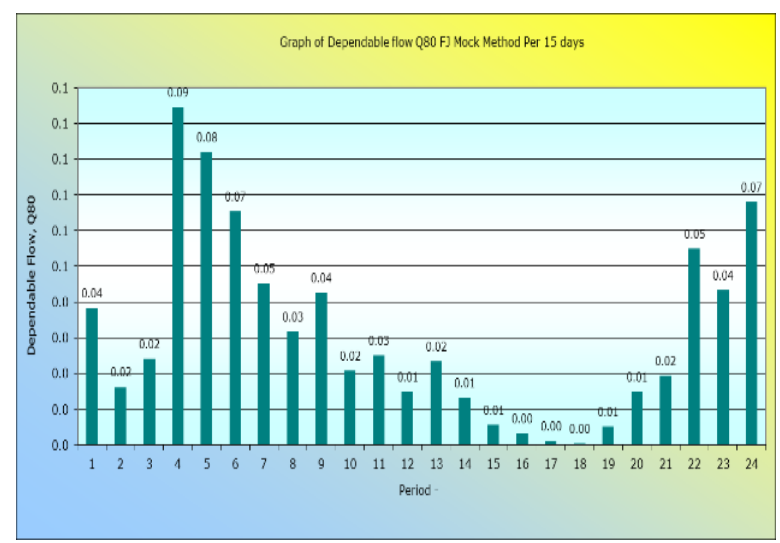

Fig. 6. Q 80 F.J. Mock Mantaren Stat. 1987-2002 (Source: Analysis Data, 2018)

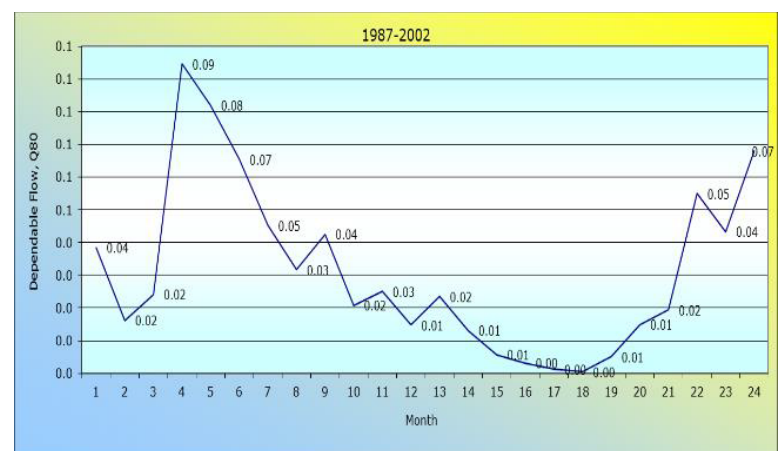

Fig.7. Water Balance per 15 days in Mantaren Stat 1987-2002 (Source: Analysis Data, 2018)
And this is the results of water balance analysis in KHG Pulang Pisau

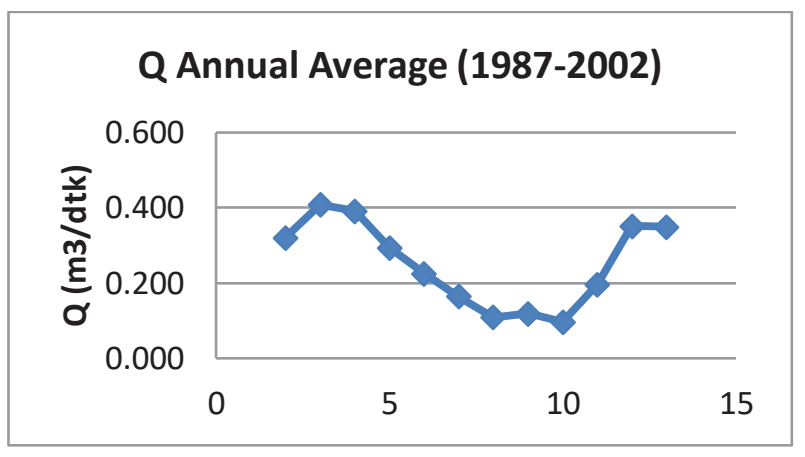

Fig.8. Water Balance in KHG Pulang Pisau

(Source: Analysis Data, 2018)

\subsection{Modflow application}

Modflow is a model of groundwater level based on the finite difference equation able to perform simulations for all types of aquifers, such as distressed aquifers, unconfined aquifers, semi-depressed aquifers, mixed aquifers [3]. The other advantages of Modflow is capable to receiving a variety of input data, the type of aquifer, layer thickness, conductuvuty hydraulics and transmissivity characteristics.

In this study, the Modflow application using plugin FREEWAT by Quantum GIS version Las Palmas. The Fig. 9 is example of worksheet Q Gis using FREEWAT plugin. Groundwater flow modeling in this research using unconfined steady conditions

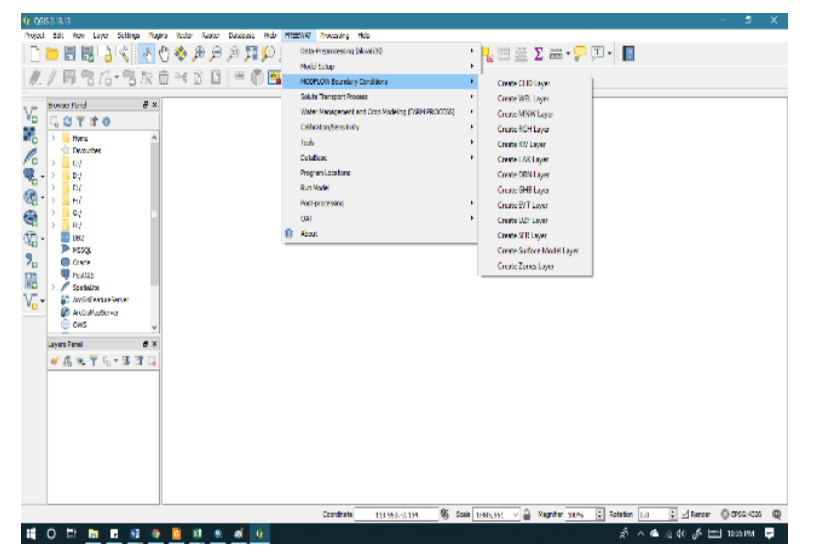

Fig. 9. Example Interface worksheet Q Gis using FREEWAT plugin.

(Source: Analysis Data, 2018)

And below, working steps of the application Modflow 


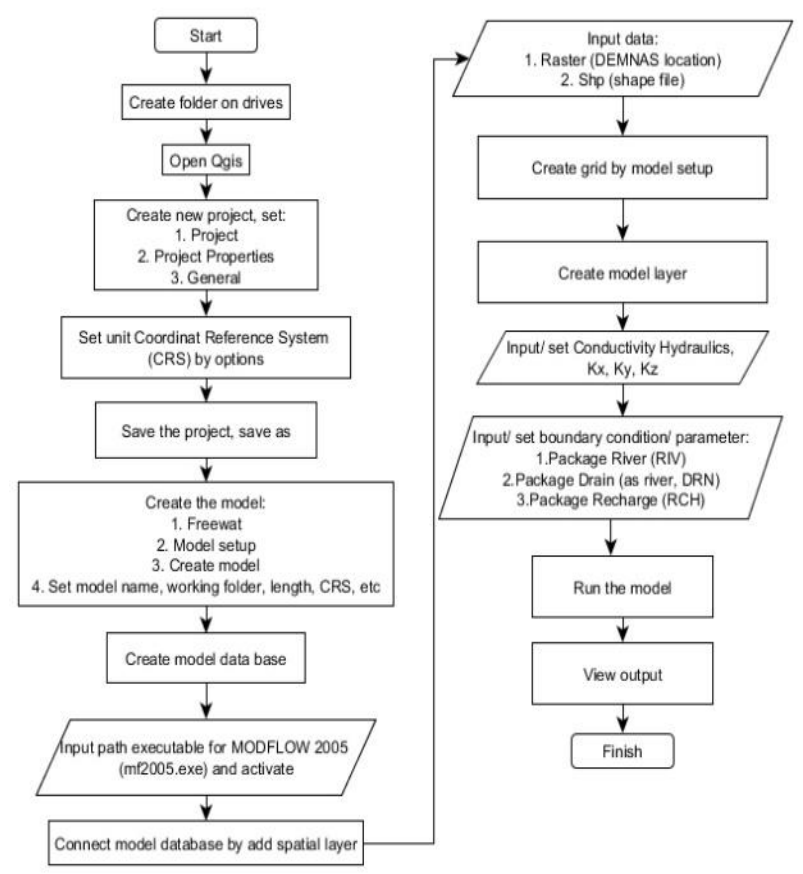

Fig.10. Flowchart modeling Modflow application

\subsection{Hydraulic conductivity}

Hydraulic conductivity has a very close relationship with the nature of aquifers. On peatlands, aquifers have a conductivity between $0.001 \mathrm{~m} /$ day $-100 \mathrm{~m}$ / day. That's $\mathrm{s}$ value is very diverse depending on substrate roughness, decomposition, and peat humification. The forming material is unconsolidated and does not experience a large load. The existing gradient head is very low due to flat landscape.

\subsection{Boundary conditions}

Modeling groundwater flow for peatland uses a finite difference scheme with a grid size of $5 \times 5$ with ratio of $1: 1$. This study reviews the behavior of peat groundwater flow patterns and water level in two conditions, namely in the rainy and dry seasons with the input parameters as follows.

a. Digital Elevation Model (DEM) data

b. Canal width:

Canal $1=6.2 \mathrm{~m}$

Canal $2=2 \mathrm{~m}$

c. Peatlands Thickness $2 \mathrm{~m}$

d. Hydraulics Conductivity of peatland $6 \times 10^{-6}$

e. Distance between canals is $50 \mathrm{~m}$

f. Canal Boundary Discharge:
1) Rainy Season
Canal $1=0.166 \mathrm{~m}^{3} / \mathrm{s}$
Canal $2=0.205 \mathrm{~m}^{3} / \mathrm{s}$
2) Dry Season
Canal $1=0.073 \mathrm{~m}^{3} / \mathrm{s}$
Canal $2=0.084 \mathrm{~m}^{3} / \mathrm{s}$

g. Recharge Boundary:

1) Rainy Season $=300 \mathrm{~mm} /$ day

2) Dry Season $=0 \mathrm{~mm} /$ day

h. Modeling by unconfined steady condition

\subsection{Groundwater flow model}

1. Rainy season

In the rainy season assumption, the results of modeling groundwater flow and water level on peatlands in Mulyasari Village as in Fig. 11.
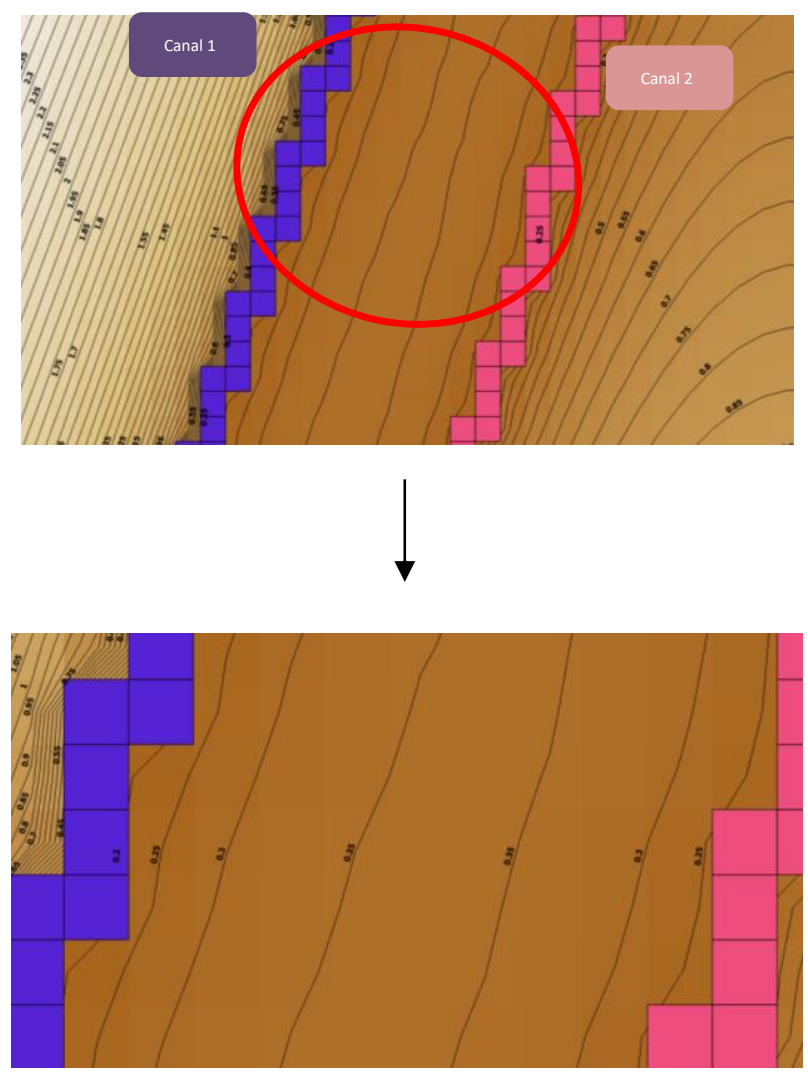

Fig. 11. Contour water surface of peatland on rainy season (Source: Result modeling ground water peatland on rainy season, 2018)

If seen in one of the grid cross sections (columns, $\mathrm{x}$ axis) or rows, y axis) the results can be seen in the Fig. 12 as follows.

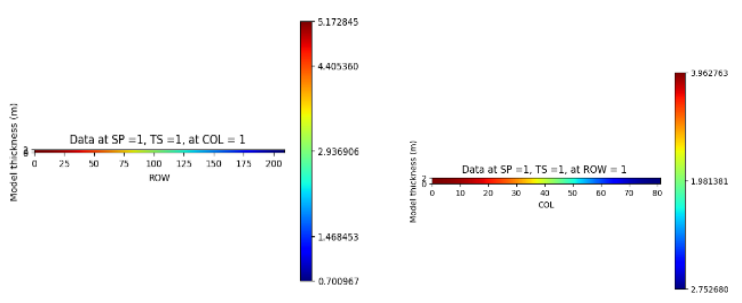

Fig.12. Water Surface of ground water peatland on Rainy season, Column and Row

(Source: Result modeling ground water peatland on rainy season, 2018)

Furthermore, to analyze the behavior of groundwater flow and water level, one canal section can be seen as in Fig. 13 


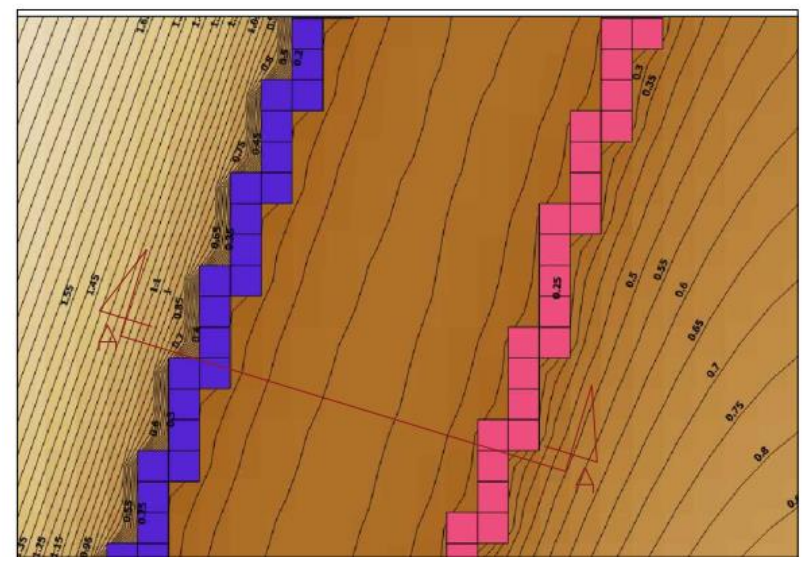

Fig. 13. Plan section A-A of result modeling ground water peatland on rainy season

(Source: Result modeling section A-A of ground water peatland at secondary canal on rainy season, 2018)

Based on the picture above, it can be seen that the groundwater level of peatlands in the rainy season between the two canals ranges from $0.2 \mathrm{~m}-0.35 \mathrm{~m}$. The modeling results show a convex-shaped surface of groundwater flow. The results were obtained based on the Q $800.405 \mathrm{~m}^{3} / \mathrm{s}$, the condition of water level on channel 1 is $0.166 \mathrm{~m}$ and channel 2 is $0.205 \mathrm{~m}$; rain that occurs at extreme conditions of $300 \mathrm{~mm} /$ day. Judging from the flow profile that occurs on A-A pieces, the flow can be seen in Fig. 14

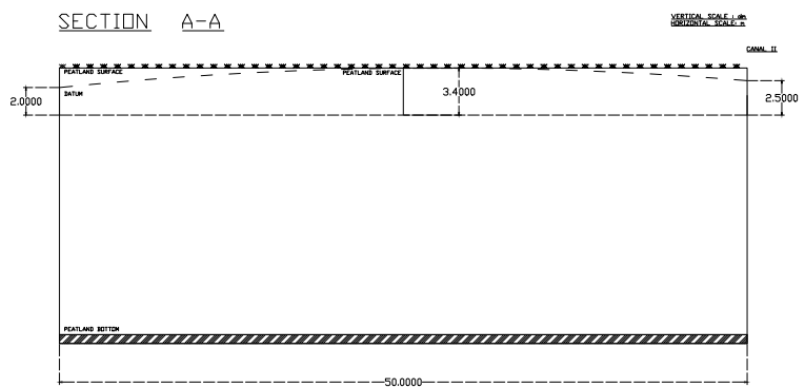

CANAL I

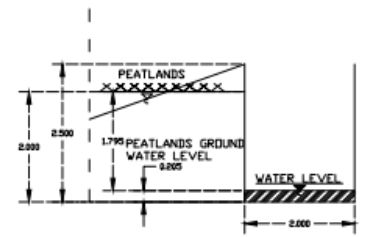

Fig. 14. Section A-A of ground water modeling at secondary canal on rainy season.

(Source: Result analysis ground water peatland profile at secondary canal on rainy season, 2018)

\section{Dry Season}

In the dry season, the results of modeling groundwater flow on peat land in Mulyasari Village are as shown in Fig. 15
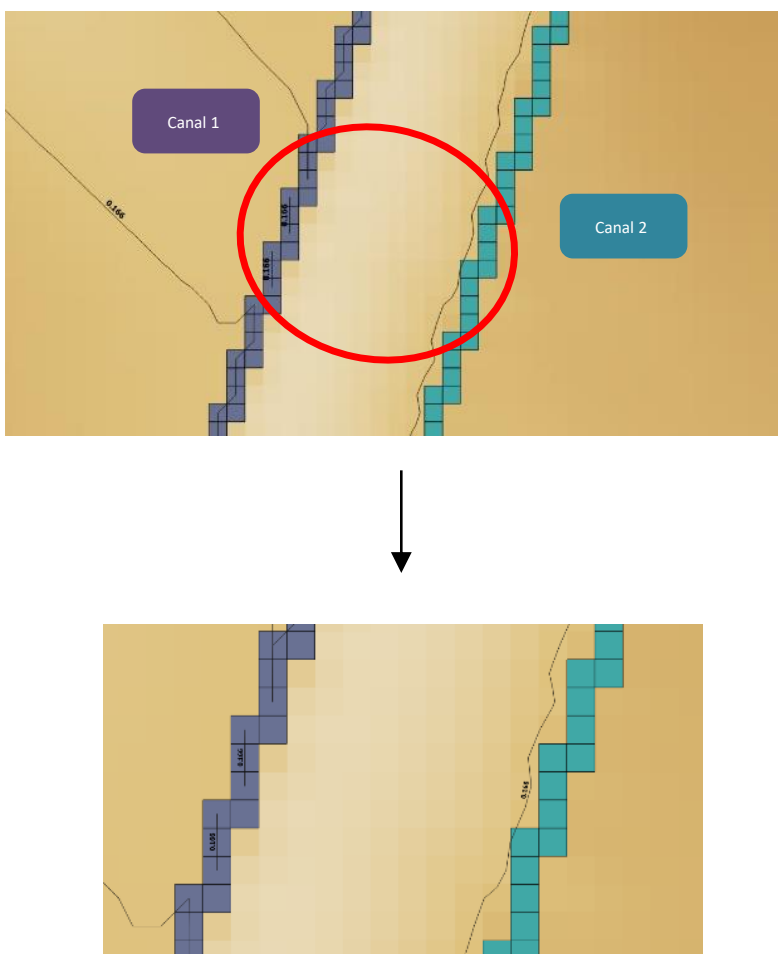

Fig. 15. Contour water surface of peatland on dry season (Source: Result modeling ground water peatland on dry season, 2018)

If seen in one grid of cross section grid (column, abscissa $\mathrm{x}$ ) or row, ordinate y) the results can be seen as in Fig. 16.

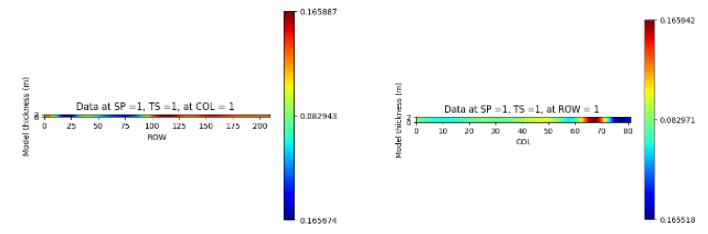

Fig. 16. Water surface of ground water peatland on dry season, column and row

(Source: Result modeling ground water peatland on dry season, 2018)

For analysis of the behavior of groundwater flow can be seen one of the channel sections as in Fig. 17

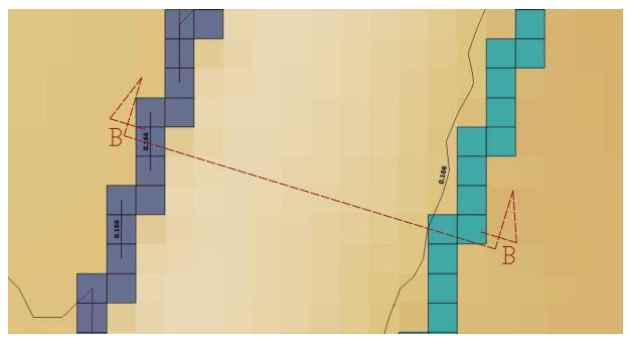

Fig. 17. Plan section B-B of result modeling ground water peatland on dry season

(Source: Result modeling section B-B of ground water peatland at secondary canal on dry season, 2018) 
Based on the picture above, it can be seen that the groundwater level of peatlands in the dry season ranges from $0.166 \mathrm{~m}-0.165 \mathrm{~m}$. Modeling shows the profile of groundwater flow which tends to clamp with a very small difference, so that if it looks flat. The results were obtained based on the Q80 is $0.084 \mathrm{~m}^{3} / \mathrm{s}$, the condition of water level in channels $10.0703 \mathrm{~m}$ and channel $2=0.084$ $\mathrm{m}$; no rain events (extreme conditions) $0 \mathrm{~mm} /$ day. Judging by the flow profile that occurs on the B-B pieces, the flow can be seen in Fig. 18

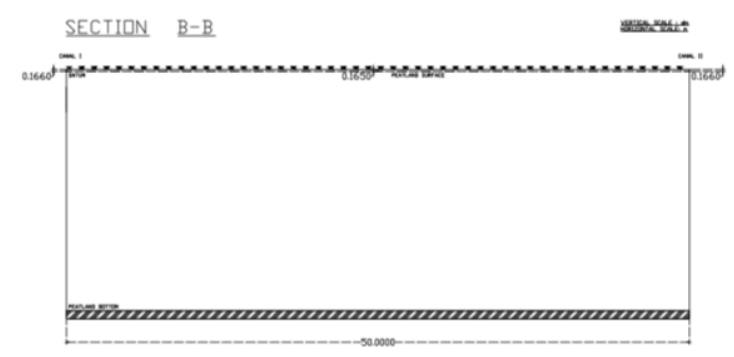

CANAL I CANAL II
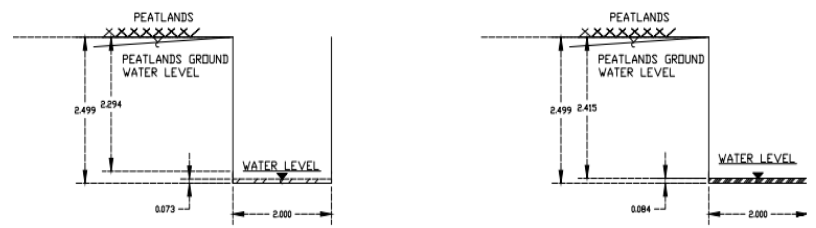

Fig. 18. Section B-B of ground water modeling at secondary canal on dry season

(Source: Result analysis ground water peatland profile at secondary canal on dry season, 2018)

Based on two results of modeling of groundwater flow of peatlands in the that conditions, if referring to Government Regulation no. 57 of 2016 concerning the Protection and Management of Peat Ecosystems which states that the lowest peat water limit is $0.4 \mathrm{~m}$, then the results of modeling in the dry season $(0.166 \mathrm{~m}-0.165 \mathrm{~m})$ and rainy season $(0.2 \mathrm{~m}-0.35 \mathrm{~m})$ need more attention.

The water management system that needs to be good management. Which is set a better location for the canal blocking installation plan by focus some parameters. They are channel width, the distance between the canals, and the flowrate that exists on each channel. This is done to prevent the flow of water quickly so that it can hold water temporarily, especially on canals with relatively close distances. In addition, the potential risk of fire that will occur can be minimized.

\subsection{Fire relations and drainage / canal systems}

The major factor for forest fires that occurred in the study area is the behavior of land clearing, the construction of large drainage channels / canals. From these activities, it can have implications for the absorptive capacity and water reservoir in the peatlands decreasing, until the drought is not reversed.

\section{Conclusion}

Based on the research study that have been carried out, it can be concluded that.

1) The potential value of water balance contained in KHG Pulang Pisau for the characteristics of palawija crops are: at rainy season, Q $80=0.405 \mathrm{~m}^{3} / \mathrm{s}$, and at dry season Q $80=0.084 \mathrm{~m} 3 / \mathrm{s}$

2) Water level of groundwater Peatland in KHG Pulang Pisau are: at rainy season $=0.2 \mathrm{~m}-0.35 \mathrm{~m}$, and at dry season $=0.166 \mathrm{~m}-0.165 \mathrm{~m}$

3) Results analyzing parameter for water managements system of Peatlands in KHG Pulang Pisau so that the peatland is not too dry and not too wet are set a better location for the canal blocking installation plan by focus some parameters. They are channel width, the distance between canals, and flowrate that exists on each channel.

\section{Suggestion}

1) Need to do the measurement of field data for calibration of modeling results.

2) Conductivity parameters of peatlands at modeling to be more variated.

3) Distance between canal to be more variated

\section{References}

1. Peat Restoration Agency of Republik Indonesia. Restoration Plan District Peat Ecosystem, Pulang Pisau. Province Central of Kalimantan (2016)

2. Central Bureau of Statistics Republic of Indonesia, Pulang Pisau Regency, Pulang Pisau in figures (2018)

3. Freewat. FREE and Open Source Software Tools for Water Resource Management. EU Horizon 2020 Project (2018)

4. Government Regulation of Republic Indonesia No. 57 2016 changes to government regulations no. 71 of 2004 concerning the protection and management of peat ecosystem (2016) 